By LOUIS B. WRIGHT

\title{
The Folger Library as a Research Institution
}

\author{
Dr. Wright is director, Folger Shake- \\ speare Library.
}

$\mathrm{O}$ NE OF the world's great repositories of source materials for the background of the history of Western civilization is the Folger Shakespeare Library in Washington, D.C. Because the word "Shakespeare" is a part of the official designation of the library, many people jump to the conclusion that the collections are restricted to the great Elizabethan dramatist.

Nothing could be farther from the truth. Actually the Folger Library has the largest collection in the Western Hemisphere of books printed in England or in English before $164 \mathrm{I}$. It is constantly adding to its collection of historical source materials for the period from the introduction of printing in England in 1476 to 1700 . These materials deal with every aspect of the life of man and are not confined to literature alone. In addition to sixteenth- and seventeenthcentury historical materials, the library has an extraordinary collection dealing with the history of the theater and drama from the beginnings down to the end of the nineteenth century, including many books and manuscripts on American theatrical history.

The wide variety of research being done in the Folger Library reflects the diversity of its source materials. Although the library has the largest Shakespearian collection in the world and makes an active effort to stimulate studies in this field, it is significant that an average of only 15 per cent of the readers applying at the Folger are interested in Shakespeare. The other 85 per cent are concerned with topics as broad as life itself.

Since the opening of the Folger Library in 1932 , its scope has been gradually broadened by the decision of the trustees of Amherst College whom Henry Clay Folger designated to manage the foundation which he established. In 1938 the trustees authorized the purchase of the remarkable collection of books printed before 1641 which $\mathrm{Sir}$ Leicester Harmsworth, the English newspaper publisher, had brought together. As a newspaper man, Harmsworth had been interested in a wide variety of topics: science, religion, philosophy, agriculture, military tactics, geography, exploration, in fact, anything which concerned the English people. $\mathrm{His}$ books reflected this diversity of interest, and served to complement Folger's original collection which had been chiefly literary, with an emphasis on Shakespeare.

The acquisition of the Harmsworth books completely transformed the Folger Library and changed its focus. From a relatively small and compact collection centered around Shakespeare, the Folger Library overnight became a library of international importance concerned with the history of Engiish civilization. The Harmsworth books more than trebled the titles of early English printed books bequeathed by $\mathrm{Mr}$. Folger.

The trustees' decision in 1938 to widen the horizons of the Folger Library was in keeping, however, with the program which Folger himself had already marked out. Al- 
though he had begun as a collector of Shakespeariana, he was shrewd enough to know that Shakespeare, or any other figure, cannot be studied in a vacuum. Accordingly he bought books about Shakespeare's age, and about the age preceding and following Shakespeare. When he died in 1930, he left an endowment sufficient for the library's continued growth in the directions which he had indicated.

Since the Folger Library already has the greatest collection of Shakespeariana in existence, it is not difficult to maintain its leadership in this area. Indeed, it would be impossible to spend the Folger's income on the further purchase of significant Shakespeariana. As a research institution the Folger is not interested in mere curiosities of casual Shakespearian interest.

The transformation of a collection of rare books into a working, research institution is a more involved procedure than anyone except a trained librarian will readily comprehend. Rare books and documents are the essential raw materials which must be organized in such a way that they may be usable instruments for the advancement of learning. An adequate catalog must be prepared. Essential reference works to make the rare books comprehensible must be gathered. Convenient working conditions must be established. A competent staff to serve the needs of research workers must be recruited. In recent years the Folger Library has been undergoing this transition from a collection of books and manuscripts to an effective research institution.

The first necessity was obviously an adequate general catalog. Within the past three years, a catalog has been prepared so that the reader can now find his material with relative ease. The long delay in the compilation of a general catalog was caused by a venture undertaken when the Folger had only about 6000 rare books printed before 1640 . It was decided at that time to make an elaborate bibliographical description of these books and eventually to print this bibliography. Most of the Catalog Department's energies were consumed with the preparation of this descriptive bibliography of the early rare books. The cost proved astronomical. In many cases descriptive cataloging cost more than the original purchase price of a book. When the Folger bought the Harmsworth Collection and vastly increased its holdings in this field, it became apparent that elaborate bibliographical cataloging could not be continued without risking bankruptcy or curtailing essential services. Accordingly, bibliographical description on the scale first undertaken has been abandoned in favor of more practical-and more useful - cataloging. Bibliographical work, of course, still goes on at the Folger Library, and specialists on the staff are available for consultation on technical problems.

The reference collection, assembled at the Folger Library and available on the open shelves, has proved of inestimable value in increasing the efficiency of both research scholars and the staff. Because the Folger is just across the street from the Library of Congress, it was at first supposed that reference books could be kept to a minimum. In theory, scholars working with rare books at the Folger could cross the street to consult critical, biographical and bibliographical works needed to make rare books effective. In practice this system proved utterly inefficient both for readers and for the Folger's own staff. Many scholars preferred to cross the continent to work in the Huntington Library, which had an excellent reference library, rather than try to carry on their research without having essential reference works at hand. As every scholar knows, it is often necessary 
to have on the same table rare books and the secondary works needed for their interpretation. Furthermore, the Library of Congress is a busy place and the secondary books required are not always available.

The apparent thriftiness of depending on the Library of Congress for essential reference works actually proved an extravagant waste. A simple cost analysis of staff time in going to the Library of Congress showed conclusively that the Folger could quickly recover the price of many expensive bibliographical works in the saving of staff time alone.

The Library of Congress, as everyone knows, has a vast collection of reference materials, all of it freely available to scholars working at the Folger. For this reason, the nearness to the national library will always be one of the attractive features of working at the Folger. We shall never make an effort to duplicate a great deal of this material, but we are trying to place on our shelves those books most needed to prevent frustration to the scholar and constant loss of time to the staff.

In its acquisition policy, the Folger's main emphasis is upon the source materials which build to the strength already possessed. We are always eager to acquire rare books in the period before $164 \mathrm{I}$, and we are actively buying both in that period and in the period between 1641 and 1700 . In short, books and documents which throw light on the background of Western civilization, especially England and America before 1700 , are the items most sought. In addition, we are constantly strengthening our theatrical and dramatic collections for the eighteenth and nineteenth centuries. When individual rare books are so expensive that we cannot hope to acquire the originals, we buy microfilm to fill in around those rarities which we already possess so that the scholar may find here as complete a col- lection as we can make of those sources which he requires. Fortunately, the rare books which the scholar wants are frequently not the rare items which make news at book auctions because of the fabulous prices they bring. For the price of a Bay Psalm Book, for example, we can acquire a whole library of seventeenth-century books far more serviceable to historians and literary scholars.

Because a library like the Folger does treasure and give infinite care to its rare books, generous donors frequently present books which are beyond the means of any institutional budget. Many beautiful books, some of which are to be seen in the exhibition gallery, have come to the Folger as gifts of public-spirited book collectors. Indeed, the research libraries of the United States owe a great debt to book collectors who have been phenomenally generous in their support and in the choice of books which they have given to these institutions.

During the past year the Folger Library has added several thousand titles of books and pamphlets printed in England in the sixteenth and seventeenth centuries. It bought nearly 3000 titles from the Harmsworth Trust, several hundred from the sale of the Shipdham Church Library in Norwich, and a considerable list of rarities from the Bridgewater Library. Perhaps the rarest item acquired during the year was Thomas Hobbes' first important contribution to political and religious philosophy, the excessively rare 1642 edition of . . De Cive. In subject matter, the acquisitions cover the whole range of man's thought and activities.

The Folger Library possesses a considerable collection of continental books significant for the history of thought or for their literary implications in the sixteenth and seventeenth centuries. It is adding to 
this material by buying those books which influenced English thought and expression.

The Folger welcomes every scholar or advanced student engaged in any worthwhile study. Last year 350 scholars from 34 states and nine foreign countries found material in the Folger Library for their books and articles. This year the number will be larger and the variety of subjects studied will be even greater.

During the two past decades, the privately endowed research libraries of the United States have assumed an increasing responsibility for the encouragement of research. They have realized that their responsibility does not end with becoming a repository of books and manuscripts. The use of these materials in the interest of learning has become a preoccupation of these libraries. The Folger, like several others, is devoting a part of its annual budget to fellowships and grants-in-aid. In every case, the recipients of such grants must be engaged upon some worth-while undertaking of genuine significance and must show a need for materials in this library.

The list of research Fellows at work in the Folger Library during the past summer is indicative of the wide range of subjects studied here. The Fellows, with their subjects, are:

L. J. Trinterud, professor of church history, McCormick Theological Seminary. The indigenous background of English Puritanism.

Willson Coates, professor of history, University of Rochester. Studies in English social history.

Rhodes Dunlap, associate professor of English, State University of Iowa. The literary career of King James I.

Pearl Hogrefe, professor of English, Iowa State College. Sir Thomas More and his literary circle.

John H. Long, professor of English, More- head State Teachers' College, Morehead, Ky. Elizabethan music.

Lucyle Hook, associate professor of English, Barnard College. The biographies of two Restoration actresses, Mrs. Bracegirdle and Elizabeth Barry.

Stoddard Lincoln, graduate student, Columbia University. Seventeenth-century use of music in the theatres.

Emmett L. Avery, professor of English, State College of Washington. The history of eighteenth-century theatres.

Fredrick L. Bergmann, associate professor of English, DePauw University. Studies in Restoration drama.

C. William Miller, professor of English, Temple University. A study of Henry Herringman.

To stimulate interest in research, the Folger holds monthly seminars attended by scholars working in the library, members of the staff, and scholars from neighboring institutions. A progress report on some area of investigation is always followed by general discussion. More popular lectures on various aspects of the history of civilization in the sixteenth and seventeenth centuries are given from time to time in the lecture hall for the general public.

The two critical centuries which the Folger Library has taken for its province are of vital significance to Americans. The patterns of our culture were marked out in these years. Without an understanding of what went on in western Europe during that period, particularly what took place in England, Americans cannot properly comprehend the development of their own civilization. The Folger Library's purpose is to provide a congenial and effective place for the investigation and interpretation of the history and the literature which have helped mold American ideas even to the present day. 